NBER WORKING PAPER SERIES

\title{
THE OWN-PRICE OF MONEY AND A NEW CHANNEL OF MONETARY TRANSMISSION
}

\author{
Michael T. Belongia \\ Peter N. Ireland \\ Working Paper 9341 \\ http://www.nber.org/papers/w9341 \\ NATIONAL BUREAU OF ECONOMIC RESEARCH \\ 1050 Massachusetts Avenue \\ Cambridge, MA 02138 \\ November 2002
}

Peter N. Ireland would like to thank the National Science Foundation for financial support through grant number SES-0213461. Any opinions, findings, conclusions, or recommendations expressed herein are those of the authors and do not necessarily reflect the views of the National Science Foundation. The views expressed herein are those of the authors and not necessarily those of the National Bureau of Economic Research.

(C) 2002 by Michael T. Belongia and Peter N. Ireland. All rights reserved. Short sections of text, not to exceed two paragraphs, may be quoted without explicit permission provided that full credit, including $\mathbb{C}$ notice, is given to the source. 
The Own-Price of Money and a New Channel of Monetary Transmission

Michael T. Belongia and Peter N. Ireland

NBER Working Paper No. 9341

November 2002

JEL No. E32, E51, E52

\section{$\underline{\text { ABSTRACT }}$}

Traditionally, the effects of monetary policy actions on output are thought to be transmitted via monetary or credit channels. Real business cycle theory, by contrast, highlights the role of real price changes as a source of revisions in spending and production decisions. Motivated by the desire to focus on the effects of price changes in the monetary transmission mechanism, this paper incorporates a direct measure of the real own-price of money into an estimated vector autoregression and a calibrated real business cycle model. Consistent with this new view of the monetary transmission mechanism, both approaches reveal that movements in the own-price of money are strongly related to movements in output.

Michael T. Belongia

Department of Economics

University of Mississippi

P.O. Box 1848

University, MS 38677

mvpt@earthlink.net

Peter N. Ireland

Department of Economics

Boston College

140 Commonwealth Avenue

Chestnut Hill, MA 02467

and NBER

irelandp@bc.edu 
The Own-Price of Money and a New Channel of Monetary Transmission

Traditionally, the effects of monetary policy actions on output are thought to be transmitted via monetary or credit channels. In the former, changes in the nominal quantity of money affect spending directly whereas, in the latter case, open market operations induce changes in interest rates that affect spending; in some models, credit rationing can have a secondary effect on output as well. Real business cycle models, in contrast, emphasize that changes in real prices can be a consequence of monetary policy actions and that economics most naturally focuses on price changes as the source of revisions in spending and production decisions. Unfortunately, estimation or calibration of real business cycle models to illustrate this theoretical proposition has been handicapped by the apparent absence of a continuous time series of price data that would reflect changes in the stance of monetary policy. Thus, the perceived lack of any price data flowing directly from actions taken by the Federal Reserve's Open Market Committee (FOMC) has led authors to examine proxies and isolated incidents rather than directlyobservable price changes over a broad span of time. For example, Romer and Romer (1989) extracted anecdotal evidence from transcripts of FOMC meetings to identify six episodes of negative monetary policy shocks associated with attempts to reduce inflation; the dummy variable that marks these decisions explains a substantial portion of the variation in output. In a similar vein, Plosser (1991) treated increases in reserve requirements between 1937-39 as an increase in the cost of deposit creation and examined that period for fluctuations in output associated with this change in the setting of one monetary policy lever. ${ }^{1}$

Motivated by the desire to focus on the effects of price changes on output as a consequence of monetary policy actions, this paper introduces a new model of monetary transmission. In it neither the nominal quantity of money nor interest rates is linked directly to output but, instead, changes in the real own-price of money are associated with aggregate fluctuations. To this end, we first discuss how the own-price of money can be 
measured in a manner consistent with results in modern aggregation theory and, in so doing, produce a continuous time series of real prices that can be used in empirical work. The characteristics of the resulting data then are examined, in overview, within a VAR framework that allows changes in a nominal measure of monetary policy (the adjusted monetary base) and changes in the real price of money to affect output separately. We then discuss a real business cycle model with the nominal quantity of money and modify it to incorporate the real price of money as well. Once specified, this model is calibrated and time paths for data generated by it are compared against actual output data. We find that the synthetic and actual data evolve along similar paths and that a direct measure of the real own-price of money appears to offer a new channel of monetary policy transmission apart from either the monetary or credit views.

\section{Measuring the Own-Price of Money}

Empirical work in monetary economics typically uses measures of the aggregate quantity of money produced by central banks. These data are called simple sum aggregates because they are unweighted, arithmetic summations of the deposits in the various categories subsumed within the aggregate. The theoretical implications of simple sum aggregation are that each asset in the index is a perfect substitute for every other asset in the group and, as such, the representative consumer has a utility function of the Leontief form. ${ }^{2}$ Alternatively, an aggregate quantity of money also can be constructed as an index of the superlative class and, in this case, quantities of index components are weighted by shares of expenditures on their monetary service flows. Here, the form of the sub-utility function for money holdings is unknown but the index number will track its value over time as changes in the relative prices of alternative forms of money induce substitutions that alter the expenditure share weights of the components and the quantities held of those deposit categories in the aggregate.

No matter what type of index is chosen to measure the aggregate quantity of money, principles of duality require that each, as a matter of internal consistency, is paired with a 
precise expression for the corresponding own-price of money. Thus, the perfect substitutability implication of the Leontief technology behind simple sum aggregation requires that the own price of the monetary aggregate be the lowest price, at time $t$, among the assets within the aggregate. ${ }^{3}$ The paragraphs below will show that this own-price will take the form of a minimum user cost. ${ }^{4}$ In contrast, the own price of aggregate money, when measured by a superlative index, will be the share-weighted sum of each asset's user cost. ${ }^{5}$ In neither case, however, is the own-price of money merely an interest rate chosen to represent the opportunity cost of foregone interest on a single alternative to money holdings.

To illustrate these points, the construction of a superlative index number begins by calculating total expenditures on the components of the aggregate. That expenditure $\left(E_{t}\right)$ can be written as $\mathrm{E}_{\mathrm{t}}=\sum x_{i t} p_{i t}$. When aggregation is over monetary assets, $\mathrm{x}_{\mathrm{it}}$ is the nominal quantity of monetary asset $\mathrm{i}$ at $\mathrm{t}$ and $\mathrm{p}_{\mathrm{it}}$ is its real price; equivalently, one can construct the expenditure magnitude by using real quantities and nominal prices. Because monetary assets are durables that do not perish during the period from use, their prices are their user costs. The formula for the real user cost of a monetary asset, derived by Barnett (1978), can be written as:

$$
p_{i t}=\left(R_{i t}-r_{i t}\right) /\left(1+R_{t}\right)
$$

where $\mathrm{R}_{\mathrm{it}}$ is a benchmark rate of return, $\mathrm{r}_{\mathrm{it}}$ is the own rate of return on the $\mathrm{i}^{\text {th }}$ component at time t. 6

With the user cost and quantity data, the expenditure share on asset $\mathrm{j}$ is $\mathrm{s}_{\mathrm{jt}}=$ $\mathrm{x}_{\mathrm{jt}} \mathrm{p}_{\mathrm{jt}} / \mathrm{E}_{\mathrm{t}}$. A Divisia quantity index in continuous time (and its Tornqvist discrete time approximation) computes the growth rate of the aggregate as the share-weighted average of its components and satisfies ${ }^{7}$

$$
\mathrm{d} \log \mathrm{X}_{\mathrm{t}}=\sum 0.5 *\left(s_{i t}+s_{i t-1}\right) d \log x_{i t}
$$

while the Divisia price index $\mathrm{P}_{\mathrm{t}}$ in continuous time satisfies 
$\mathrm{d} \log \mathrm{P}_{\mathrm{t}}=\sum 0.5^{*}\left(s_{i t}+s_{i t-1}\right) d \log p_{i t}$.

Behavior of the Simple Sum and Divisia Price Duals

Figure 1 illustrates the behavior of percentage changes in the real price of money as measured by nominal price duals deflated by the geometric mean of the GDP deflator and the CPI. With a variety of aggregates that might be examined, we have chosen to examine data for simple sum and Divisia measures of an aggregate consisting of M1 assets plus savings deposits. Although this aggregate is not reported by the Federal Reserve, it has been examined by Rotemberg, et al. (1995) and named "M1-plus" by Belongia (1996). More important for issues regarding aggregation, however, this grouping possesses the property of weak separability such that it is a candidate for aggregation; by contrast, M2 fails this test. 8 Thus, studies that have created a Divisia measure of M2 still have been in error because they have applied a legitimate index number formulation to a group of commodities that fails the first test (weak separability) in the construction of an aggregate data series. The simple sum price dual for this asset collection is a mixture of the user costs of other checkable deposits and savings deposits issued by thrifts. An exception to this general result occurred during the period of 1983-1986 when money market deposit accounts (MMDAs) were reported separately rather than as part of savings deposits; during this interval, the user cost of MMDAs represented the lowest user cost in the simple sum aggregates.

Despite the fundamental differences in the manner each series is constructed, figure 1 shows that the two follow the same broad patterns; this picture is reinforced by a comparison of values for the means and standard deviations of the series. And, while both series demonstrate considerable variability, Augmented Dickey-Fuller tests show that each is stationary. Finally, from an economic standpoint, it is interesting to note that sharp increases in the price of money tend to be associated with the on-set of recessions, whereas sharp declines appear to lead economic expansions. A potential explanation for this pattern 
in the data and more detailed exploration of its economic consequences is the focus of the real business model derived and discussed later.

\section{$\underline{\text { A Small VAR Model }}$}

How the monetary price dual might be associated with aggregate activity can be examined by comparing its contribution to the variance decomposition of output fluctuations relative to that of the nominal quantity of money. Within such an approach, it also is possible to compare both the quantitative and qualitative implications derived from otherwise identical models that use simple sum or superlative index numbers. For these purposes, a VAR model was estimated with the growth rates of real, per capita GDP (y), the adjusted monetary base (AMB) and the real price of money (pdual) as the system's endogenous variables. The model was estimated with quarterly data over a sample spanning 1960:2- 2001:4. Two lags were used for each variable and experimentation with longer lags did not affect the results in a meaningful way.

The impulse-response functions shown in the top panel of figure 2 indicate that innovations to the monetary base contribute little to fluctuations in output whereas innovations to the Divisia M1-plus price dual are related negatively to output growth. The variance decomposition statistics reveal that about five percent of the variance of output growth can be attributed to the price dual whereas less than 0.5 percent is associated with the monetary base. The same VAR, when estimated with the real simple sum price dual, yields similar results with innovations to the own-price of money showing a larger impact on output growth than that associated with innovations to base growth. Indeed, with plots of the two price measures in figure 1 showing similar behavior over time, this result is not surprising.

Modification of the VAR, however, highlights how measurement issues can affect the quality of empirical work. To illustrate the point, the VAR with the simple sum price dual is augmented by the addition of a term reflecting the difference between the growth rate of the Divisia and simple sum price duals as a separate term. The effect of this change is shown 
in the bottom panel of figure 2. In this case, the difference between the two price measures has a larger effect on output growth than innovations to the monetary base and this effect is nearly as large as that associated with innovations to the simple sum price dual itself.

Thus, while an investigation based on simple sum monetary aggregates would be internally consistent if it measured the own-price of money as the minimum real user cost among the component assets, it would be throwing away information contained in superlative index numbers.

Over all, these figures lend credence to a RBC story that would attribute output fluctuations associated with monetary policy to a change in prices rather than the nominal quantity of money. Any observed empirical associations among these series, however, occur in the absence of a theoretical model that would rationalize them. The next section discusses a model in which the real price of money, as well as its nominal quantity, have the potential to affect output.

The Model: Overview

The model borrows elements from real business cycle models with money developed in King and Plosser (1984) and Coleman (1996) as well as from the shopping time model of McCallum and Goodfriend (1987). The economy consists of a representative household, a representative firm, a representative bank, and a monetary authority. The activities of each of these agents are now described in turn.

The Representative Household

The representative household enters each period $t=0,1,2, \ldots$ with $M_{t-1}$ units of currency, $B_{t-1}$ bonds, and $K_{t}$ units of capital. At the beginning of the period, the household receives $T_{t}$ additional units of currency in the form of a lump-sum transfer from the monetary authority. Next, the household's bonds mature, providing $B_{t-1}$ more units of currency. The household uses some of this currency to purchase $B_{t}$ new bonds at the price of $1 / r_{t}$ dollars per bond, where $r_{t}$ denotes the gross nominal interest rate between $t$ and $t+1$. 
After this initial bond-trading session, the household is left with $M_{t-1}+T_{t}+B_{t-1}-B_{t} / r_{t}$ units of currency. It divides this currency up into an amount $N_{t}$ to be used to purchase goods and an amount $M_{t-1}+T_{t}+B_{t-1}-B_{t} / r_{t}-N_{t}$ to be deposited in the bank. The household also borrows $L_{t}$ dollars from the bank, bringing the total nominal value of its deposits to (1) $D_{t}=M_{t-1}+T_{t}+B_{t-1}-B_{t} / r_{t}-N_{t}+L_{t}$.

During period $t$, the household supplies $h_{t}$ units of labor and $K_{t}$ units of capital to the representative firm, receiving credit for $W_{t} h_{t}+Q_{t} K_{t}$ in return, where $W_{t}$ denotes the nominal wage rate and $Q_{t}$ denotes the nominal rental rate for capital. The household purchases output from the representative firm at the nominal price $P_{t}$; it divides its purchases into an amount $C_{t}$ to be consumed and an amount $I_{t}$ to be invested. Making these transactions requires

(2) $s_{t}=\gamma_{N}\left(\frac{C_{t}+I_{t}}{N_{t} / P_{t}}\right)^{\chi_{N}}+\gamma_{D}\left(\frac{C_{t}+I_{t}}{D_{t} / P_{t}}\right)^{\chi_{D}}$

units of shopping time, where $\gamma_{N}>0, \chi_{N}>1, \gamma_{D}>0$, and $\chi_{D}>1$. By investing $I_{t}$ units of output during period $t$, the household increases its capital stock during period $t+1$ according to

$$
K_{t+1}=(1-\delta) K_{t}+I_{t} \text {, }
$$

where $1>\delta>0$.

At the end of period $t$, the household owes the bank $r_{L t} L_{t}$ dollars, where $r_{L t}$ is the gross nominal interest rate on loans. At the same time, however, the bank owes the household $r_{D t} D_{t}$ dollars, where $r_{D t}$ is the gross nominal interest rate on deposits. After all of these transactions are settled, the household carries $M_{t}$ units of currency into period $t^{+} 1$, where

(4) $M_{t}=N_{t}+W_{t} h_{t}+Q_{t} K_{t}+r_{D t} D_{t}-P_{t}\left(C_{t}+I_{t}\right)-r_{L t} L_{t}$.

The household, therefore, seeks to maximize the expected utility function 
(5) $E \sum_{t=0}^{\infty} \beta^{t}\left[\ln \left(C_{t}\right)-\eta\left(h_{t}+s_{t}\right)\right]$,

with $1>\beta>0$ and $\eta>0$, subject to the constraints (1)-(4), each of which must hold for all $t$ $=0,1,2, \ldots$

The Representative Firm

The representative firm hires $h_{t}$ units of labor at the nominal wage $W_{t}$ and $K_{t}$ units of capital at the nominal rental rate $Q_{t}$ in order to produce $Y_{t}$ units of output according to the constant-returns-to-scale technology described by

(6) $Y_{t}=K_{t}^{\alpha}\left(Z_{t} h_{t}\right)^{1-\alpha}$,

with $1>\alpha>0$. In (6), the productivity shock $Z_{t}$ follows a random walk with positive drift:

(7) $\ln \left(Z_{t}\right)=\ln (z)+\ln \left(Z_{t-1}\right)+\varepsilon_{z t}$

where $z>1$ and the zero-mean, serially uncorrelated innovation $\varepsilon_{z t}$ is normally distributed with standard deviation $\sigma_{z}$. The firm acts to maximize its profits, equating the marginal product of labor to the real wage $W_{t} / P_{t}$ and the marginal product of capital to the real rental rate $Q_{t} / P_{t}$.

The Representative Bank

During period $t$, the representative bank makes loans worth $L_{t}$ dollars and accepts deposits worth $D_{t}$ dollars. It receives interest on its loans at the gross rate $r_{L t}$ and pays interest on its deposits at the gross rate $r_{D t}$. Let $\theta, 1>\theta>0$, denote the required reserve ratio. Assuming that $r_{L t}>1$, the bank will never find it optimal to hold excess reserves; hence

(8) $L_{t}=(1-\theta) D_{t}$

will hold for all $t=0,1,2, \ldots$ 
During period $t$, the bank creates deposits with total real value $D_{t} / P_{t}$ using a technology that requires $x_{t}\left(D_{t} / P_{t}\right)$ units of output, where the financial-sector cost shock $x_{t}$ follows the first-order autoregression

(9) $\ln \left(x_{t}\right)=\left(1-\rho_{x}\right) \ln (x)+\rho_{x} \ln \left(x_{t-1}\right)+\varepsilon_{x t}$.

In (9), $1>\rho_{x}>0, x>0$, and the zero-mean, serially uncorrelated innovation $\varepsilon_{x t}$ is normally distributed with standard deviation $\sigma_{x}$. Hence, the bank's nominal profits during period $t$ are

(10) $\Pi_{t}=\left(r_{L t}-1\right) L_{t}-\left(r_{D t}-1\right) D_{t}-P_{t} x_{t}\left(D_{t} / P_{t}\right)$.

Since competition in the banking industry drives these profits to zero, (8) and (10) imply that

(11) $r_{D t}=1+(1-\theta)\left(r_{L t}-1\right)-x_{t}$

must hold for all $t=0,1,2, \ldots$, indicating that the financial-sector cost shock $x_{t}$ impacts directly on the deposit rate $r_{D t}$ in equilibrium.

The Monetary Authority

In equilibrium, $M_{t}=M_{t-1}+T_{t}$ and $B_{t}=B_{t-1}=0$ for all $t=0,1,2, \ldots$. Substituting these conditions, together with (8), into (1) confirms that in this economy, the monetary base $M_{t}$ equals currency $N_{t}$ plus reserves $\theta D_{t}$. Let $\mu_{t}=M_{t} / M_{t-1}$ denote the gross rate of money base growth and assume, for simplicity, that the monetary authority conducts policy so that $\mu_{t}$ follows the first-order autoregression

(12) $\ln \left(\mu_{t}\right)=\left(1-\rho_{\mu}\right) \ln (\mu)+\rho_{\mu} \ln \left(\mu_{t-1}\right)+\varepsilon_{\mu t}$,

where $1>\rho_{\mu}>0, \mu>1$, and the zero-mean, serially uncorrelated innovation $\varepsilon_{\mu t}$ is normally distributed with standard deviation $\sigma_{\mu}$.

$\underline{\text { Solution, Calibration, and Results }}$

Solution 
Equations (1)-(12), when combined with the first-order conditions describing the optimizing behavior of the representative household and firm, form a large system of nonlinear stochastic difference equations. After these equations are log-linearized around the system's unique steady state, they can be solved using standard methods, such as those described by Blanchard and Kahn (1980). The theory's implications then can be explored numerically once the model is fully calibrated-that is, once specific values are assigned to each of the model's parameters.

\section{Calibration}

Since the model is built around a standard, real business cycle framework, many of its parameters can be assigned values used throughout the literature on real business cycles. For example, the depreciation rate $\delta$ is set equal to 0.025 ; with each model period interpreted as a quarter year in real time, this choice corresponds to an annual depreciation rate for physical capital of 10 percent. Similarly, the setting $\beta=0.99$ implies that the representative household's annual discount factor is 4 percent. The setting $\eta=2.7$ implies that the household spends about one-third of its time- or eight hours out of twenty-fourworking. Finally, the setting $\alpha=0.33$ dictates that capital receives a one-third share of national income; labor receives the remaining two-thirds.

Values for other parameters can be assigned so that the model matches key statistics that are computed from the postwar US data. For example, the setting $z=$ 1.00464 implies that the annualized steady-state growth rate of output in the model is 1.87 percent, equal to the average annual growth rate of real, per-capita GDP in the US from 1959 through 2001 . The setting $\sigma_{z}=0.0088$ for the standard deviation of the innovation to the productivity shock makes the standard deviation of output growth in the model equal to the standard deviation of real, per-capita GDP growth in the US data.

The parameter $\theta$, which measures the required reserve ratio in the model, is set equal to 0.0475 , based on the observation that from 1959 through 2001, the average ratio of required reserves to the deposits included in the M1-plus measure of money is also about 
4.75 percent. Similarly, setting $x=0.011$ for the average marginal cost of creating deposits allows the steady-state user cost of deposits in the model to match the postwar average of user costs of the deposits included in the M1-plus monetary aggregate. With $\gamma_{N}=0.00004$ and $\gamma_{D}=0.008$, the steady-state currency-output and deposit-output ratios from the model coincide with the average currency-output and deposit-output ratios in the US data. The setting $\sigma_{x}=0.145$ for the standard deviation of the financial-sector cost shock allows the model to replicate the standard deviation of the growth rate of the Divisia M1-plus price dual as measured in the US data. Finally, the parameters of the money supply rule (12) are set to match the results from a regression of the quarterly growth rate of the US adjusted monetary base, 1959:1 through 2001:4, on a constant and its own lagged value: $\mu=1.0167$, $\rho_{\mu}=0.46$, and $\sigma_{\mu}=0.007$

In the absence of any obvious way of linking the model's three remaining parameters to statistics constructed from the US data, values for these parameters are chosen that seem reasonable or, at least, do not seem unreasonable. The settings $\chi_{N}=2$ and $\chi_{D}=2$ imply that the shopping-time functions for currency and deposits introduced in (2) are both quadratic. The setting $\rho_{x}=0.75$, meanwhile, implies that the financial-sector cost shock is more persistent than the shock to the growth rate of the monetary base, but less persistent than the shock to productivity.

Results

Figures 3 - 5 display, respectively, the impulse responses of four of the model's variables -- output growth, monetary base growth, Divisia M1-plus growth, and the growth rate of the Divisia M1-plus price dual -- to each of the model's three shocks: To productivity, to the cost of creating deposits, and to the growth rate of the monetary base.

In this flexible-price monetary model, as in the basic real business cycle model, productivity shocks represent the dominant source of output fluctuations. A positive technology shock $\left(z_{t}\right)$ permanently increases the level of output; hence, in figure 3, it 
temporarily increases the growth rate of output. Under the simple monetary policy rule described by (9), the monetary base is an exogenous variable; hence, it does not respond at all to the productivity shock. Nevertheless, the positive technology shock and the resulting increase in output lead to an endogenous rise in the deposit-currency ratio, causing the growth rate of Divisia M1-plus to increase endogenously as well. Therefore, a positive correlation between the growth rates of output and the Divisia monetary aggregates emerges from this model, even in the case where productivity shocks are the sole force driving business cycle dynamics. The nominal interest rate movements set off by the productivity shock lead to an increase in the user costs of both currency and deposits, also leading to a rise in the Divisia M1-plus price dual.

The financial-sector cost shock $\left(x_{t}\right)$ represents the model's closest analog to the innovation in the growth rate of Divisia M1-plus price dual identified earlier in the US data. Just as in the data, this shock generates a decline in output growth. Remarkably, the 0.18 percentage-point decline in output growth for the model, shown in figure 4, coincides almost exactly with the decline in output growth in the data, shown in figure 2.

In this flexible-price model, which includes none of the traditional Keynesian or monetarist sources of monetary nonneutrality, shocks to the rate of monetary base growth $\mu_{t}$ affect real variables through inflation-tax effects alone. Hence, in figure 5 , the shock to monetary base leads to a small decline in output growth. Growth in Divisia M1-plus increases, reflecting the increase in currency, reserves, and deposits facilitated by the policy-induced increase in the monetary base. Once again, interest rate movements following the policy shock cause the Divisia M1-plus price dual to rise.

Overall, these impulse responses give rise to the impression that, while the model produces little or no correlation between the exogenous growth rate of the monetary base and the growth rate of output, it does show a positive correlation between the endogenous growth rate of the Divisia M1 monetary aggregate and the growth rate of output. In the model, in fact, the correlation between monetary base growth and output growth is -0.0116 ; 
the correlation between Divisia M1-plus growth and output growth is 0.2175. Moreover, the impulse responses from the model and the data suggest that large changes in the real value of the Divisia M1-plus price dual play a key role in generating this endogenous money-output relationship.

\section{Conclusions}

While most macroeconomic models incorporate a link between changes in the nominal quantity of money and aggregate fluctuations, real business cycle models emphasize the role of price changes on spending and production decisions. Empirical evaluation of this role has been difficult, however, because it has not been clear how the effects of monetary policy actions could be summarized in a single price variable, especially if the rate of interest is viewed as the price of credit rather than the price of money. This paper offers a solution to the measurement problem by introduction of the economic price dual to the monetary quantity aggregate. Evaluation of this measure's impact on output growth indicates that it exerts a stronger influence than that of the monetary base and, in particular, that increases in the own-price of money are associated with declines in output. Moreover, the results indicate that the Divisia price dual contains more information than that of the simple sum measure. 


\section{$\underline{\text { References }}$}

Barnett, William A. "The User Cost of Money," Economics Letters, Vol. 1, No. 2,(1978), pp. 145-49

. "Which Road Leads to Stable Money?" Economic Journal (July 1997), pp.

1171-85.

, Douglas Fisher and Apostolos Serletis. "Consumer Theory and the Demand for Money," Journal of Economic Literature (December 1992), pp. 2086-2119.

, Edward K. Offenbacher and Paul Spindt. "The New Divisia Monetary

Aggregates," Journal of Political Economy, (December 1984), pp. 497-505.

Belongia, Michael T. "Measurement Matters: Some Recent Results in Monetary

Economic Re-Examined," Journal of Political Economy (October 1996), pp. 1065-83).

. “Consequences of Money Stock Mis-measurement: Evidence from Three

Countries," in, M.T. Belongia and J. Binner (eds.) Divisia Monetary Aggregates: Theory and

Practice, London: Palgrave (2000).

Blanchard, Olivier Jean and Charles M. Kahn. "The Solution of Linear Difference

Models Under Rational Expectations.” Econometrica 48 (July 1980): 1305-1311.

Boschen, John, and Leonard O. Mills. "The Relation between Narative and Money

Market Indicators of Monetary Policy," Economic Inquiry (January 1995), pp. 24-44.

Coleman, Wilbur John II. "Money and Output: A Test of Reverse Causation.”

American Economic Review 86 (March 1996): 90-111.

Diewert, W. Erwin. "Exact and Superlative Index Numbers," Journal of

Econometrics (May 1976), pp. 115-45.

. "Superlative Index Numbers and Consistency in Aggregation,"

Econometrica (July 1978), pp. 883-900.

. "Aggregation Problems in the Measurement of Capital," in, Daniel Usher

(ed.), The Measurement of Capital (1980), pp. 433-539. 
Goldfeld, Stephen M. "Demand for Money: Empirical Studies," in, J. Eatwell, et al. (eds.) The New Palgrave: Money, New York: W.W. Norton, (1987).

King, Robert G. and Charles I. Plosser. "Money, Credit and Prices in a Real Business Cycle," American Economic Review (June 1984), pp. 363-380.

Kydland, Finn and Edward C. Prescott. "Business Cycles: Real Facts and Monetary Myth," Federal Reserve Bank of Minneapolis Quarterly Review (Spring 1990), pp. 3-18.

McCallum, Bennett T. and Marvin S. Goodfriend. "Demand for Money: Theoretical Studies.” In John Eatwell, Murray Milgate, and Peter Newman, eds. The New Palgrave Dictionary of Economics. London: Macmillan Press Ltd., 1987.

Plosser, Charles I. "Money and Business Cycles: A Real Business Cycle Interpretation," in, Michael T. Belongia (ed.), Monetary Policy on the Seventy-Fifth Anniversary of the Federal Reserve System, Norwell, MA: Kluwer Academic Publishers (1991), pp. 245-274.

Romer, Christina D. and David H. Romer. "Does Monetary Policy Matter? A New Test in the Spirit of Friedman and Schwartz," NBER Macroeconomics Annual (1989), pp. 121-170.

Rotemberg, Julio J., John C. Driscoll and James. M. Poterba. "Money, Output and Prices: Evidence from a New Monetary Aggregate," Journal of Business and Economic Statistics (January 1995), pp. 67-83.

Swofford, James and Gerald Whitney. "Nonparametric Tests of Utility Maximization and Weak Separability for Consumption, Leisure, and Money," Review of Economics and Statistics (August 1987), pp. 458-64.

Theil, Henri. Economics and Information Theory. Amsterdam: North-Holland (1967). 
Figure 1. Plots of Growth Rates of Divisia and Simple Sum Price Duals for the M1-plus Monetary Aggregate

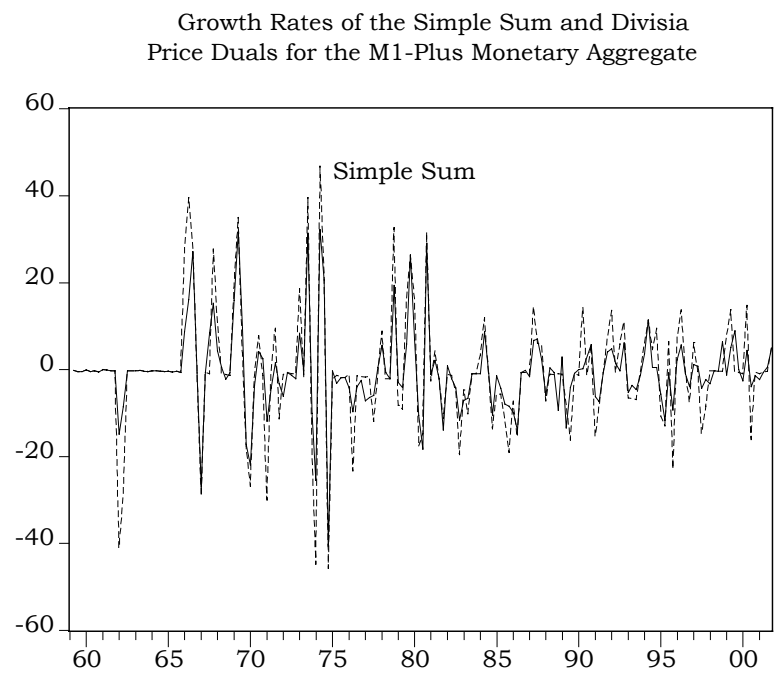

Differences Between Divisia and Simple Sum Price Duals

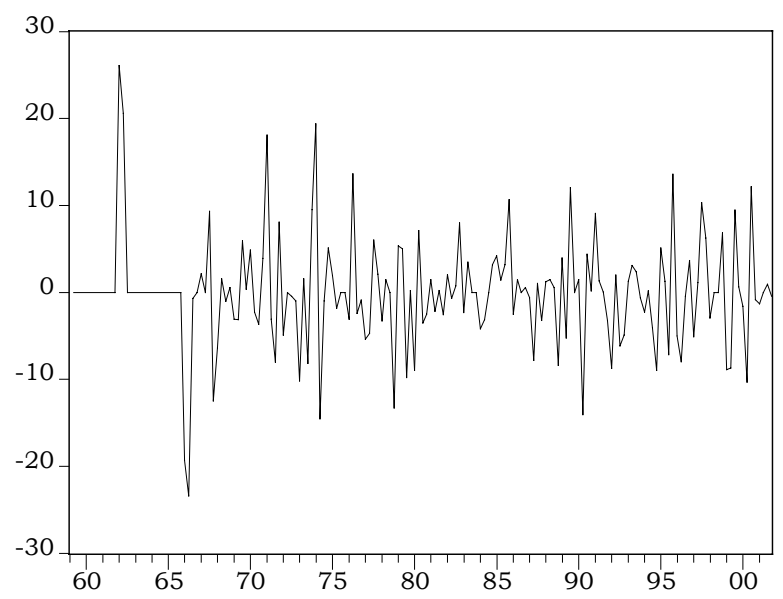

Divisia Price Dual

ADF Statistic

Mean

Standard Deviation
$-5.67$

$-0.48$

9.4
Simple Sum Dual

$-5.60$

$-0.43$

13.5 
Figure 2. Impulse Response Functions from a VAR Including Output, Monetary Base and the Own-price of Money

Response of Output Growth to One S.D. Innovations in Growth Rates of Monetary Base and Divisia M1-Plus Price Dual

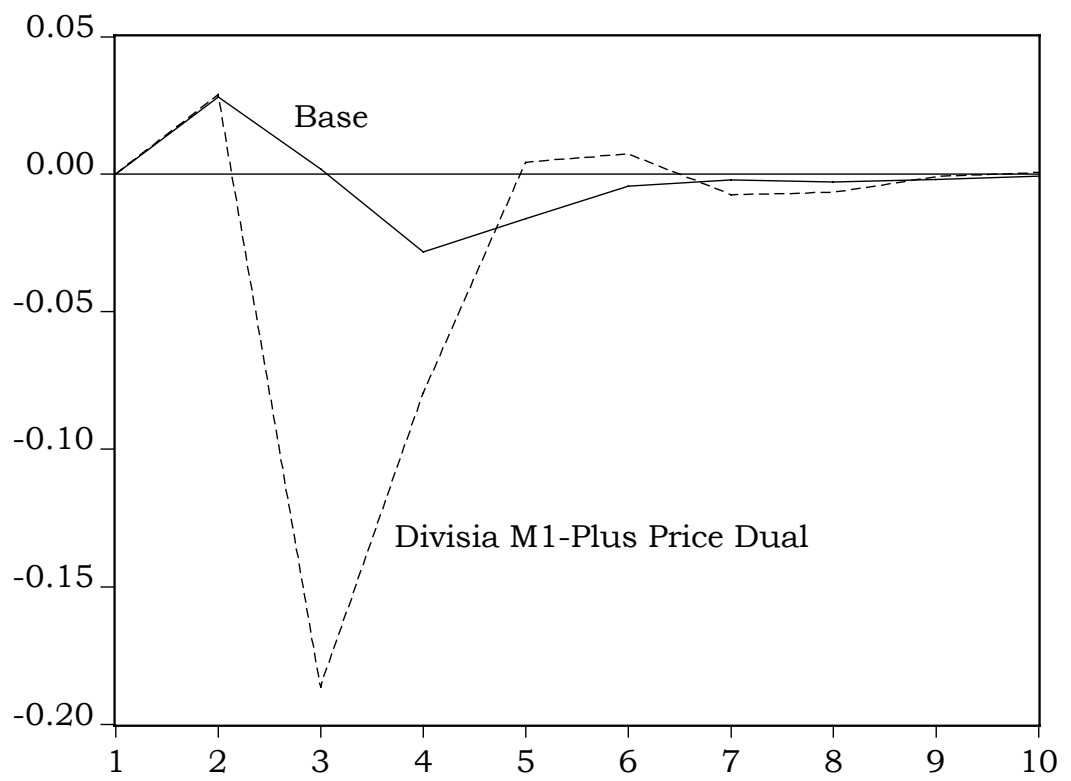

Output Response to One S.D. Innovations in Base Growth, Simple Sum Price Dual and Difference between Divisia \& Sum Price Duals

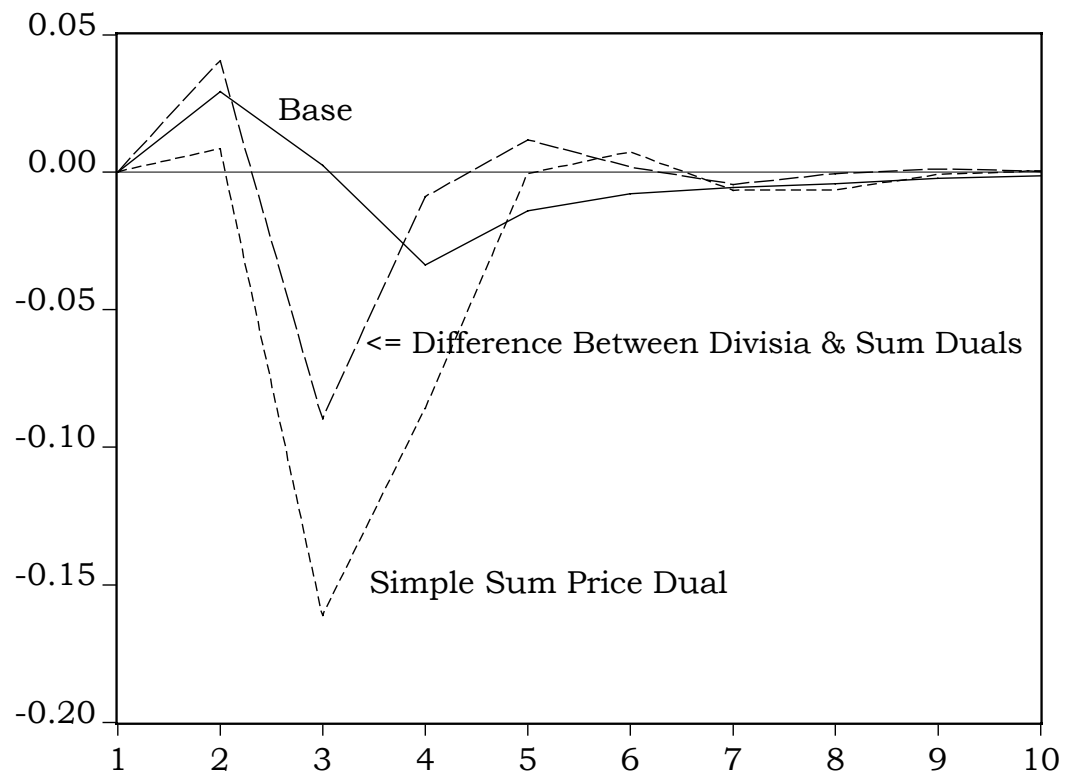




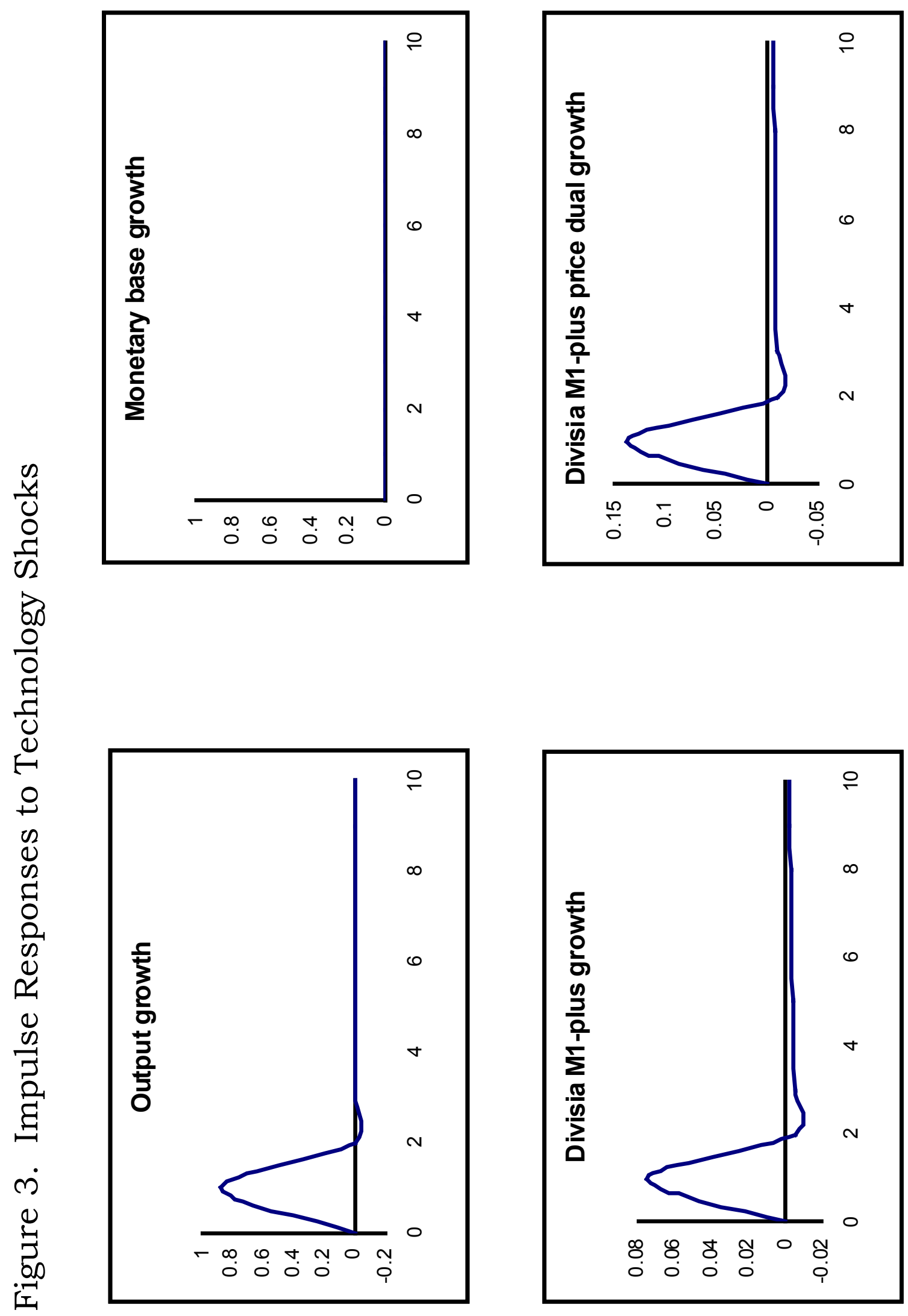



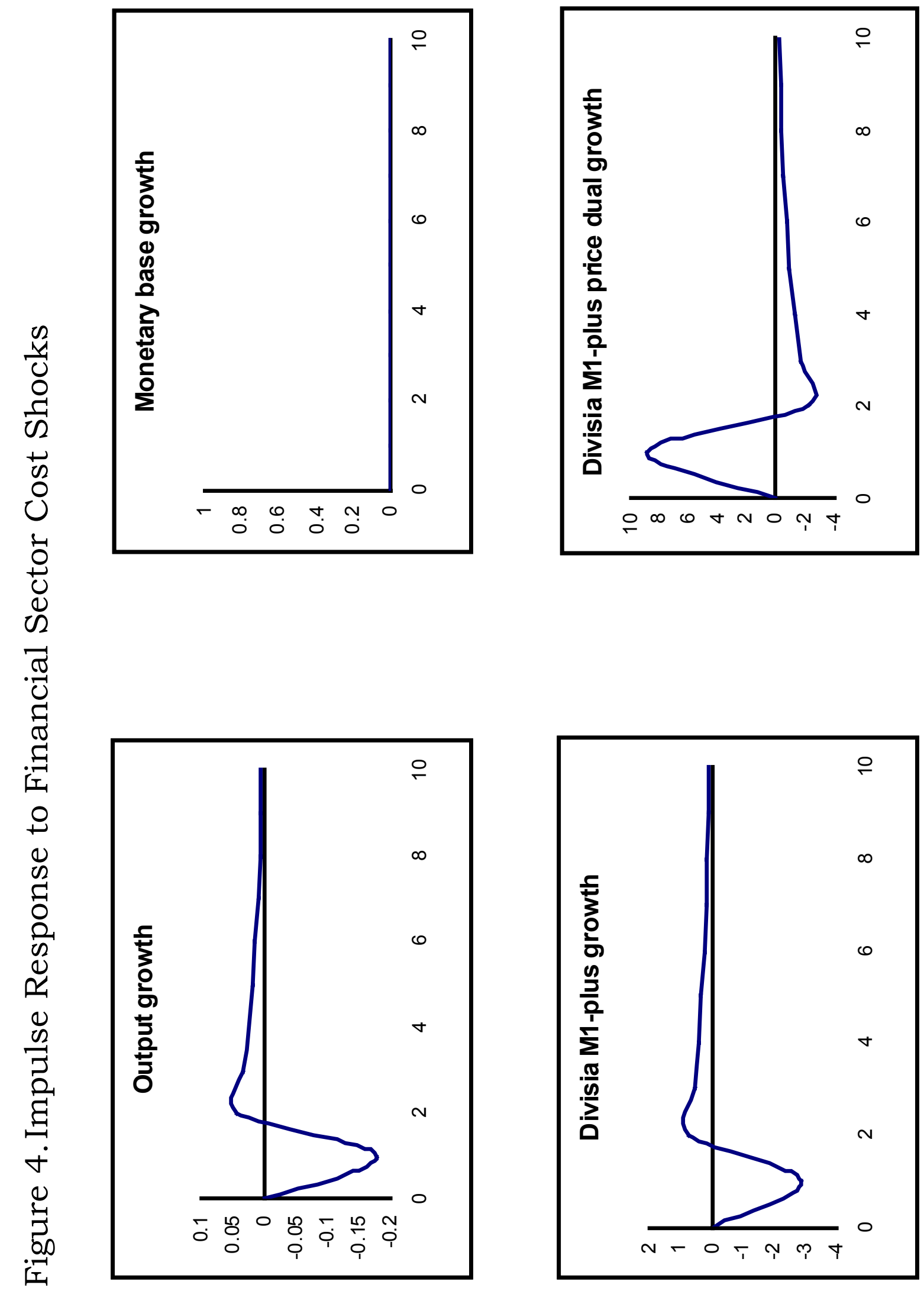

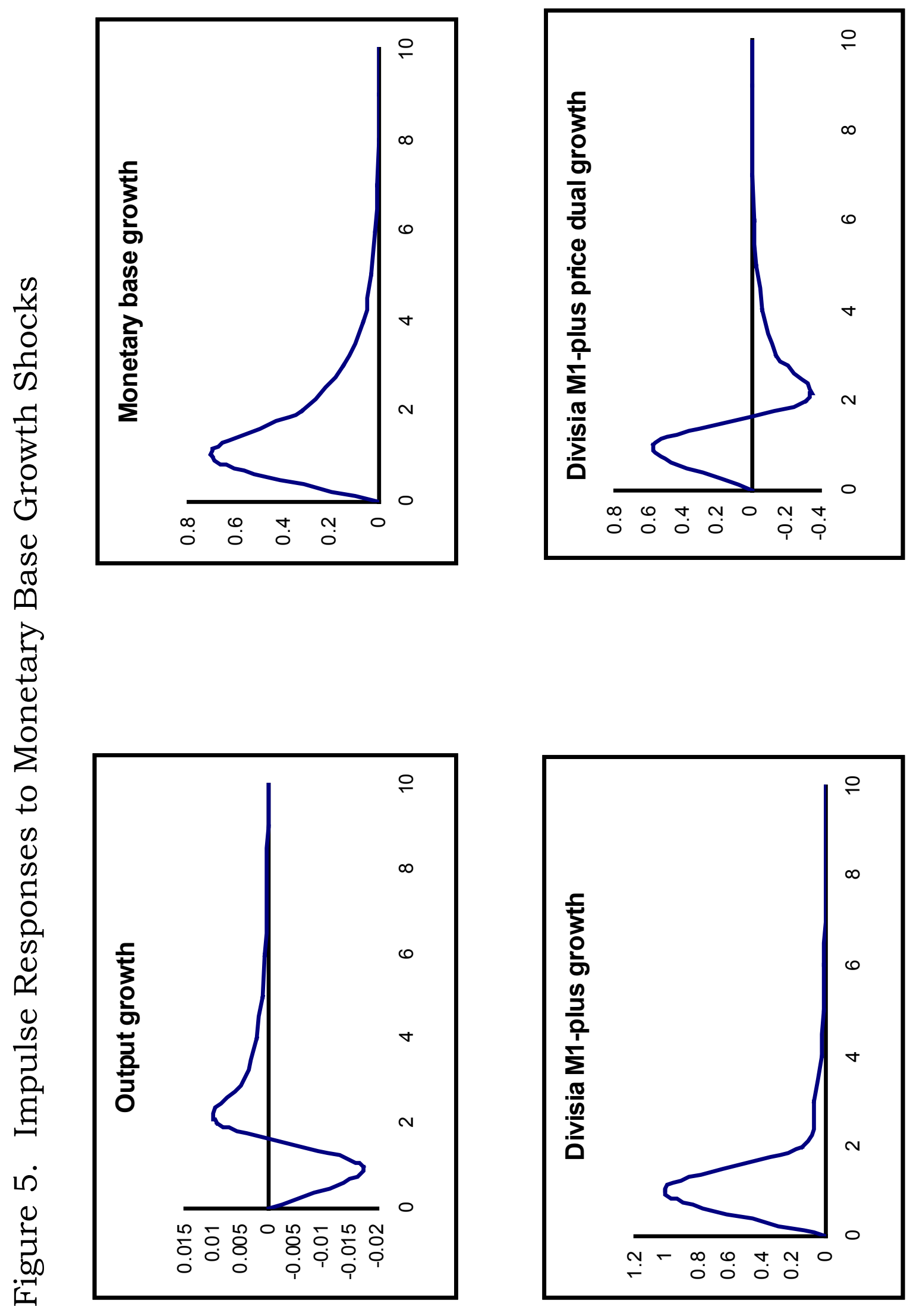


\section{$\underline{\text { Footnotes }}$}

1 Although some might regard the policy stance index of Boschen and Mills (1995) as being representative of this concept, it is arbitrary in its construction and does not focus directly on a single real concept, such as reserve requirements. Also see Kydland and Prescott (1990) for another study motivated by the idea that variables other than the nominal quantity of money are primarily responsible for fluctuations in real activity.

2 Moreover, such an index does not internalize pure substitution effects such that the index value may change even though the value of the monetary service flow from a stock of money holdings is unchanged.

3 This result offers a well-defined and unique answer to the long-standing debate about the relative merits of short- v. long-term interest rates as a measure of the own price of money in money demand functions: It is neither because aggregation theory requires that the own-price measure must be the price dual to the quantity aggregate. Long- or shortterm interest rates more generally are regarded correctly in this function as prices of substitute or complementary assets that can shift the demand for money, rather than a price variable that represents movements along the demand curve's length. This implies that most empirical demand for money functions have been mis-specified in the sense of omitting a proper measure of money's own price and not being able to identify a movement along the curve's length from a shift in the demand curve's position.

4 While it is true that the asset with lowest user cost also will be that earning the highest rate of return, the nonlinear transformation in the user cost formula does not permit simply using maximum rates of return.

5 Goldfeld (1987, p. 135) intuited as much when he pointed out that:

"Measuring this implicit rate of return is no easy matter. Matters are considerably more complicated when broader definitions of money are used and some components of money bear explicit interest, especially when there are several components each carrying a different rate of return. The aggregate own rate of return would then be a complex function of interest rates, shares, and elasticities of each of the components." 
6 In principle, the benchmark rate of return would be the return on a completely illiquid asset with the example being the return on human capital in a world without slavery. As a matter of practice, the benchmark rate has been the maximum own-rate among the assets in the aggregate at time t. An explanation for this choice is offered in Barnett, et al. (1992). 7 Notice that the Divisia index formula is not self-dual because $\left(\mathrm{X}_{\mathrm{t}}, \mathrm{P}_{\mathrm{t}}\right)$ are not a dual pair; this result was reported by Theil (1967) and occurs because the weights in a Divisia index are average expenditure shares across two periods. This result is analogous to the fact that if one uses the Laspeyres index for a quantity index, then one should not use the Laspeyres price index with it, but rather the Paasche price index, which is the dual to the Laspeyres. So (Laspeyres, Paasche) are dual pairs, but (Laspeyres, Laspeyres) and (Paasche,Paasche) are not dual pairs for (quantity, price). So neither Laspeyres nor Paasche indexes are selfdual. But in the case of the Tornqvist approximation to Divisia, $\mathrm{P}_{t}^{*}$ is very close to $\mathrm{P}_{\mathrm{t}}$ and $\mathrm{X}_{\mathrm{t}}$ is very close to $\mathrm{X}^{*}$. With the errors between the two formulae for quantity (or the two quantities for price) of a third order magnitude in the changes, studies still use a Divisia index both for quantity and for price and ignore the tiny violation of Fisher's factor reversal test. The Fisher ideal index is self dual, but the Fisher ideal along with all other index numbers in Diewert's superlative class are equal to each other to within the roundoff error of the component data, and the Tornqvist approximation has its own advantages.

8 This asset collection has been shown by Belongia (2001) and Swofford and Whitney (1987) to be a weakly-separable asset group that meets a sufficient condition for aggregation. More generally, however, aggregating over an admissible asset grouping (i.e., a collection of monetary assets that is weakly separable from other assets and goods) is critical to any evaluation of index numbers. For example, the continued use of simple sum M2 has been defended because it appears to have a stable demand function. The M2 asset collection, however, is not weakly separable and, as such, fails to satisfy a basic condition for any economic aggregate; specifically, the results in Belongia (2001) for the U.S., 
Germany and Japan, indicate that the inclusion of time deposits in a monetary aggregate is responsible for the violation of separability conditions. Moreover, as Barnett and Zhou (1994) have discussed, the inherent instability of simple sum aggregates has led to a continual broadening in their coverage to induce, for some unknown length of time, the artificial and illusory stability that can be associated with aggregating over wider ranges of objects. That is to say, they predict that simple sum M3 eventually will be become the choice for empirical studies once simple sum M2 begins to show instability. 